\title{
Uma tribo, é isso que eu sou
}

\author{
Jan Fabre
}

diálogo para duas vozes

Voz 1

Uma tribo

É isso que eu sou

Esse "eu" estranho

Que nunca a civilização

controlou

Eu vou limpar minha alma

Para me renovar

Para cair

E para me torturar

Com uma dor de dentes insuportável

Com gengivas inflamadas

E uma terrível câimbra nos maxilares

Que me absorve totalmente

E me faz romper com tudo

Até o ponto de não

Tocar mais a vida

Até o ponto em que o desaparecimento se revela

Eu vou limpar a minha alma

E não vou parar

Antes de encontrar a paz

Antes de parar de me perder nos meus pensamentos

Antes de me libertar da dor de ser livre
Essa dor ardente

Sentir os pensamentos que se deslocam

Estar sempre a caminho

E jamais parar

Em mim

Eu não vou parar de

Limpar minha alma

Camada após camada

Até que reste apenas

A calcificação esférica

De um único pensamento

Eu sou um espírito queixoso

Que não sabe como agir

E que toma sempre o caminho incerto

Da mortificação delirante que é sua vida

Que gravita apenas nos despenhadeiros escarpados

Para examinar o estrangulamento do seu ser

Pssss, pssst, pssst, pssss, pssst,

Pssss

Eu sei

Eu perdi a minha língua

Mas isso não dá a vocês

o direito de continuar

Eu desconfio

Dessas merdas peremptórias

Texto publicado em Jan Fabre, "Une tribu, voilà ce que je suis" (excerto), in L'Histoire des larmes et autres pièces, versão francesa de Olivier Taymans, Paris, L’Arche, 2005, p. 167-85. Tradução de Sílvia Fernandes. 
Que etiquetam

As criações e o pensamento

Pssss, pssst, pssst, pssss, pssst,

Pssss

Eu desconfio dos cantores de ópera

Esses funcionários gordos e

bem pagos

que escarram sons em sua alma com

a precisão de flechas castradas

Pssss, pssst, pssst, pssss, pssst,

Pssss

Eu desconfio dos compositores

Essas putas de opereta que vomitam notas

E copiam uns dos outros as

Melodias afetadas

A golpes de mouse no computador

Pssss, pssst, pssst, pssss, pssst,

Pssss

Eu desconfio dos atores

Esses travestis maquiados demais

Que só sabem falar quando

Alguém lhes escreve um texto

E parecem papagaios mecânicos

Pssss, pssst, pssst, pssss, pssst,

Pssss

Eu desconfio dos escritores

Esses escrevinhadores plagiários

Que deixam seu espírito traficado girar

Ao sabor dos ventos, como cata-ventos

Pssss, pssst, pssst, pssss, pssst,

Pssss

Lá onde outros propõem criações

Eu só quero mostrar

Meu espírito implicante

Eu não quero mais lamentar isso

Pois eu perdi a minha língua

Pssss, pssst, pssst, pssss, pssst,

Pssss
O que estou fazendo?

Talvez eu tenha apenas uma tarefa!

Eu mordo a mão de Deus

Eu não solto os dentes

Continuo a morder até ser lavado

Pelos jatos de sangue de Deus

Eu não devo me purificar

Porque ele me cega

Estou destinado a ser um vidente

Que não vê

Eu erro

Eu flutuo

Voz 2

Há muito tempo não vejo mais a terra

Mas meus pés estão cheios de bolhas

Voz 1

Eu não vou parar

Camada após camada

Eu vou limpar minha alma

até que reste apenas

a calcificação esférica

de um único pensamento

Eu sou o velho cão

selvagem

Que vê as cores do arco-íris

E que geme e chora sob a lua e

Sob o sol

Pssss, pssst, pssst, pssss, pssst,

Pssss

Um esqueleto destroçado

Envolvido por músculos finos e ardentes

Raquíticos e crispados

Como se fosse feito de vidro

E frágil

(...) 